\title{
THE RESIDENTIAL REAL ESTATE MARKET IN POLAND
}

\author{
Ewa Siemińska \\ Nicolaus Copernicus University, Gagarina Street 11, 87-100 Toruń, Poland \\ E-mail:ewahsiem@econ.umk.pl
}

Received 15 October 2011; accepted 30 December 2011

\begin{abstract}
The paper presents the functioning of the Polish residential real estate market from the perspective of the construction and financial sectors. Developers operating on a dynamic market must respond quickly and flexibly to the changes occurring on the market, e.g., at the growth stage they should be increasing their investment portfolios, while during the slowdown stage they should be taking measures to maintain the scale of their business, or be reducing the price of the developed area. The paper also shows the involvement of the banking sector in financing the real estate market, which affects majorly the dynamics of the real estate market development.
\end{abstract}

Keywords: residential real estate market, financing, investment, developer, Poland.

JEL Classification: R31.

\section{GYVENAMOJO NEKILNOJAMOJO TURTO RINKA LENKIJOJE}

\author{
Ewa Siemińska \\ Mikalojaus Koperniko universitetas, Gagarina g. 11, 87-100 Toruń, Lenkija \\ El.paštasewahsiem@econ.umk.pl
}

Iteikta 2011-10-15; priimta 2011-12-30

Santrauka. Straipsnyje pateikiami Lenkijos gyvenamojo nekilnojamojo turto rinkos funkcionavimo aspektai, atsižvelgiant ị statybų ir finansų sektorių perspektyvas. Programų kūrẻjai (plètotojai), veikiantys dinaminèje rinkoje, privalo operatyviai ir lanksčiai reaguoti ị rinkoje vykstančius pokyčius, pavyzdžiui, augimo etape jie turètu didinti investiciju portfeli, o lètejjimo etape - numatyti priemones išlaikyti savo verslo apimtis arba mažinti išplètotų zonų kainas. Straipsnyje atskleista bankų sektoriaus veikla (dalyvavimas) finansuojant nekilnojamąj turtą, kuri turi įtakos nekilnojamojo turto rinkos plètros dinamikai.

Reikšminiai žodžiai: gyvenamojo nekilnojamojo turto rinka, finansavimas, investicijos, plètotojas (programų kūrejjai), Lenkija. 


\section{Introduction}

Similar to the international residential real estate market, the Polish real estate market is subject to cyclical changes, to changes initiated by domestic and global market conditions, and to behaviours of various market players, particularly on the demand side. Making investments on the residential real estate market is a venture that is burdened with abundant risk. These risks become even more powerful under extreme conditions and, therefore, market players need to adapt a very cautious approach while dealing with them. One of the underlying risk factors is a current macroeconomic situation of a country's major foreign business partners. Uncertainty, the risk potential related to the financial sector and the solvency of the EU zone member countries and the United States, and the economic slowdown in Asia result in the fear of the possibility of the occurrence of another turmoil on the financial markets and an increase in the aversion to taking risk and, consequently, of the outflow of capital to safer markets (Report NBP 2011).

The objectives of the paper are analysis and evaluation of the situation on the Polish residential real estate market after the world's financial turmoil initiated on the US mortgage market. Special attention was paid to the developers who had to face the economic turbulences at various stages of the preparation and implementation of their investment projects financed mostly with bank loans. Moreover, the situation of the banking sector involved in financing of the demand declared by individual customers as well as corporations was presented. Additionally, banks' lending policy was described in short.

The following research methods were applied in the paper: a critical analysis of the subject literature, a dynamic analysis of the statistical data concerning the present situation on the Polish real estate market and the banking sector, a logical comparative analysis, synthesis and inference.

The paper is based on the latest reports and analyses of the Polish residential real estate market and the situation in the banking sector in the first decade of the twenty-first century. On this basis a dynamic analysis of the phenomena under research was conducted.

\section{Conditions for making investments on the Polish real estate market}

Since the financial crunch in the mid-2007 dynamic changes have taken place on the Polish market. After the major economic parameters, such as, for instance, Poland's GDP, the volume of investment outlays, or the scale of the foreign direct inflow had improved, the second half of 2008 saw a significant downturn in various sectors of the economy including the real estate market. The substantial slowdown in the investment realized by developers in 2009 and the cautious approach taken in investment decisions at the beginning of 2010 constituted the manifestation of investors' adaptation to a dynamically changing business environment and of the awareness of the risk faced. This awareness necessitated a modification of the already made decisions. A lot of individual and corporate investors, including developers, drastically reduced, shifted over time or resigned from the realization of the projects that had previously been incorporated into their investment strategies. Other market players were forced to resell, frequently at reduced prices, their projects being at various stages of advancement. Yet another group of investors were taken over together with their projects by entities of better financial standing (Palm 2011).

All investment decisions, including ones on allocating the investor's capital on the real estate market are immanently connected with risks (Knight 1921); however, it needs to be emphasized that risks do not concern only the investor(s) but also a large group of direct and indirect participants on this market (Lorenz et al. 2006). Moreover, these risks reveal themselves with doubled force under the conditions that are extreme, marginal, or require market participants to be exceptionally cautious. However, when indicating major sources of risk, the following ought to be distinguished:

- macroeconomic,

- mezzoeconomic - sectoral,

- microeconomic - generating the risk related to a specific property and all the stakeholders of the transaction.

The macroeconomic sources of risk occurring on the real estate market include, e.g., the demographic situation resulting from, among other things, migration phenomena, which directly affects the demand for real estate and enlivens the credits market (Pyhrr, Born 1994; Stiglitz 2010) as well as technological solutions available on the market that determine building materials used or architectural designs. Other conditions of risk-generating investment processes include legal, financial and fiscal regulations, which are important particularly for foreign investors whose investment activity must additionally comply with the provisions of international cooperation agreements, levels of capital availability and diversification that influence directly the demand on the market as well as the stability of the financial sector. The economic practice of numerous countries seems to prove that the intensity and scale of investments made on the real estate market may affect significantly the strengthening of the market trends throughout the whole economy. Moreover, the well-known tight relation between the banking sector and the real estate market necessitates leveraging capital-consuming investments which generates a specific risk level and profile. As proved by plentiful examples, that risk may threaten financial stability of borrowers and then, through various transmission channels, spread over the whole global economy. It is commonly thought that too excessive engagement of the banking sector in financing investment projects is a source of the crises in the whole financial sector. Also, important is the fact that the real estate market undergoes cyclical changes 
and reacts strongly particularly during the stages of growth and recession and impacts significantly other sectors of the economy (Renaud 1995; Dehesh, Pugh 1996).

The sectoral (mezzoeconomic) sources of risks connected with investments on the real estate market are the risks which are specific to a given market segment on which the investment is being made, mainly in projects related to the exploitation of natural resources, the energy sector, road, rail or air transport, hydrological infrastructure, etc.

The group of risks connected with investments of a microeconomic character and made on the real estate market, as indicated earlier, refers to a specific investment project and the project's stakeholders. This group includes the risks that concern:

- the scale of the project,

- the financial liquidity which absolutely conditions the actual realization possibilities of the project,

- the concept of the project that is related to the strategy assumed for it to be realized at the use stage,

- the accepted technological solutions including the innovation level and, which is absolutely essential, safety assurance at the design, realization, and exploitation stages,

- the specific character of applied legal solutions, in particular in concluded agreements,

- the number and reliability of the stakeholders involved in the investment project and the timely realization of the project,

- the impact of the project on the environment, first of all, on the natural environment for which every investment at the stage of realization or during exploitation is, in fact, interference in the state hitherto of the environment with its specific environmental balance,

- the social climate that decides the level of social acceptance for a project or the lack of such acceptance which stems from, among other things, the quality and reliability of the image created for the project,

- the choice of location for a given investment undertaking - decisions made within this scope generate the so-called risk of planning conditions linked with insufficient knowledge on the planned purposes of the use of a specific plot of land or modifications in the local land development plan (Krajewska 2011).

The year 2010 in the Polish economy saw a return to the situation from before the economic slowdown of the period of 2008-2009. The change covered all the key spheres of activity including financing and investing on the real estate market. Similar trends could be noted in 2011 and that time period was characterised by a relatively stable and high level of mortgage loans granted to households. The forecast for 2012 predicts growth in the Polish GDP at the level of
$3.5-4.5 \%$ which impacts positively the prediction concerning the intensity of investment including investment on the real estate market. Moreover, the opportunity to use abundant financial means coming from the European Union funds has triggered a significant increase in the investment activity of commercial and public investors. Also, the organization of the 2012 UEFA European Football Championship in Poland has initiated numerous investment projects, especially infrastructural ones, connected with constructing new roads and sports objects which are frequently financed by the European Union funds. It can be seen that Poland counts among the countries that make the best use of the European Union funds.

Poland's large attractiveness to foreign investors seems to be proved by the United Nations Conference on Trade and Development (UNCTAD), according to which Poland is ranked in the sixth position on the list of the countries that are the most attractive investment targets for the years 2011-2013. The UNCTAD report claims that Poland is preceded only by China, USA, India, Brazil and Russia. As was emphasized by experts, this good result achieved by Poland is owed to a relatively stable condition of the Polish economy during the global crisis when Poland managed to reach a positive GDP in the year 2009 as the only country in the European Union.

The latest report prepared by Ernst and Young (2011) also proves Poland's being attractive to foreign investors. The report qualifies Poland as an attractive European investment target. As follows from the report, Poland occupies the third position in Europe (after the United Kingdom and France) as regards the number of jobs created as a result of foreign direct investment (12.4 thousand). The majority of the investment concerned the commercial segment of the real estate market; in more detail, it concerned such industries as manufacture of radio and TV equipment, car manufacture, logistic centres and business services. As regards the source countries, most of the capital invested in Poland comes from businesses from the United States. As pointed out by experts in the above-mentioned report, Poland has been perceived as a leading investment target among the Central and Eastern European countries due to its big potential of the domestic market, stable and positive economic growth, and well-educated employees. The advantages listed are appreciated by foreign investors and they encourage them to locate various types of investment projects in Poland.

A mention should be made here that during the aforementioned economic slowdown, foreign investors were the first to withdraw their capital from Poland and searched for other investment targets, which always causes an increase in the risk of the loss of stability of the host country's economy. Such behaviours initiate further reactions among other market players who, while assessing the business risk, frequently make marginal evaluations depending on the current stage of the business cycle (Siemińska 2010):

- from underestimating risks, especially in the upper stage of the business cycle which is revealed in a large 
availability of capital and an increase in the exposition of the bank's offer, growth in demand, low risk premiums, low changeability of prices, and in the growth of 'appetite' for taking risks,

- to overestimating risks at the stage of decrease in the business cycle,

- and underestimating risks in extreme situations.

\section{The development of the residential real estate market}

The above-mentioned conditions that impact investors' behaviours based on the example of the residential real estate in Poland are illustrated with the data provided by the Main Statistical Office. The data represent the number of dwellings completed, or whose construction was begun, or for which the permit to build was issued in the time period of 1989 until the end of Q3 2011 (Fig. 1).

The largest number of dwellings whose construction was commenced can be seen in the following six agglomerations: Warsaw, Cracow, the Tricity metropolitan area (Gdańsk Sopot - Gdynia), Łódź and Poznań which altogether represent $60 \%$ of the market and, if considered by value, the participation reaches $75 \%$ of the market. The analysis of the data concerning the years 2010 and 2011 shows a significant increase in the offer in the majority of Polish towns. The increase has been caused not only by the occurrence of new investments on the market but also by the restarting of the sale of numerous projects in which investment had been temporarily suspended due to the crisis. In the mid-2011 the number of dwellings on sale reached the level similar to that from before the crisis and it outreached the results obtained in the first quarter of 2010 by $36 \%$. It is estimated that in the mid-2011 over 46 thousand of completed dwellings were offered to customers. The big supply and a relative stabilization of the demand on the residential real estate market have led to an increase in competition on the market and to the dominance of dwellings with lower and medium standards whose total surface does not exceed 55 square meters. The dominance concerns both dwellings which are at the stage of realization and the interest shown in new dwellings.

Due to a relatively high saturation of the Polish market with the ready to sell residential real estate and to growing competition, some developers in order to strengthen their financial standing decided to lower prices of dwellings offered on the primary market. The downward trend in prices could be observed between 2008 and the beginning of 2011 and the decrease was 5-15\% depending on the transaction (in some cases the decrease exceeded even 15\%). Besides, a lot of developers with a view to encouraging customers to buy completed dwellings started to apply, apart from the aforementioned price reduction, various incentives and promotions such as, for example, a free parking lot, a free extra utility room, kitchens equipped with household appliances or travel coupons. However, such promotional activities were taken usually in the case of the sale of dwellings which had been built in the previous years and were still uninhabited.

The above-mentioned downward trend in prices on the residential real estate market changed slightly in the second quarter of 2011 due to, among other things, the introduction of new designs with the most demanded surface of a higher standard and located on more expensive but more attractive

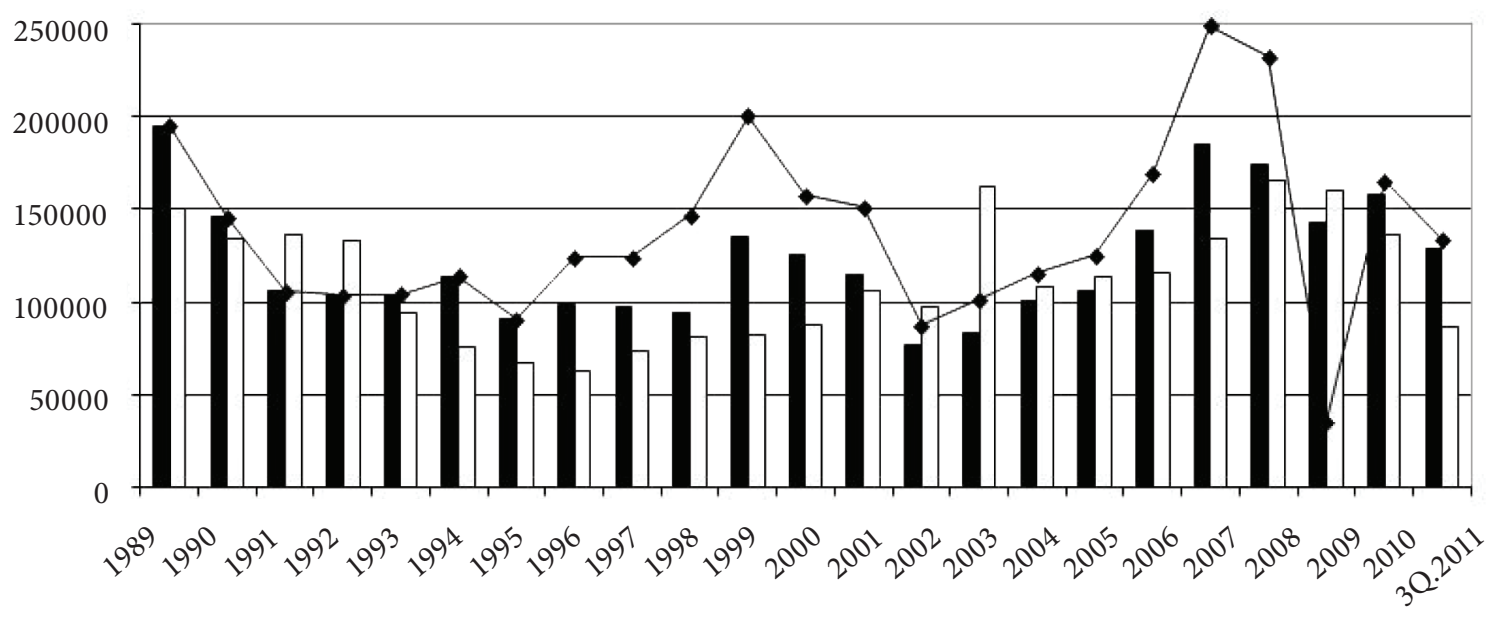

Dwellings in which construction was begun
Dwellings completed
Dwellings for which permints to build were issued

Fig. 1. The number of dwellings completed, or whose construction was begun, or for which the permit to build was issued in the years 1989-2011 (Source: The construction industry - performance results in 2011. GUS Warsaw 2011) 
building plots. As predicted by experts, this trend should maintain throughout the whole of the 2011 year. The levels of prices in major Polish cities in the time period 2008-2011 are shown in Figure 2 below.

The scale of the demand for residential real estate is the derivative of the availability of bank loans and the levels of interest charged on them. It was as early as in the fourth quarter of 2008, so during the already seen global crisis, when the drastic decrease in the banking action was revealed in relation to both individual and corporate clients. The decrease resulted from the fact that banks tightened the criteria applied for assessing clients' creditworthiness and for credit conditions because of the worsening of the financial situation in the banking sector. Generally, changes in banks' credit policies consisted in verifying information on clients and on the actual value of offered loan securities in a more rigorous manner. At the turn of 2008 and 2009 and throughout 2009 banks for the purposes of the quality and integrity of the verification of loan applications (apart form the aforementioned activities) started to use more restrictive criteria for assessing potential clients' creditworthiness. These are as follows:

1. Regarding retail clients:

- increasing the level of the income required,

- showing preference to clients with more regular income (that is why persons living alone or working abroad are given lower assessments by banks),

- carrying out more realistic assessments (increases) of the costs considered in the creditworthiness evaluation procedure such as monthly subsistence costs as per one family member and the maintenance costs of the real estate securing the bank loan,

- requiring from clients a certain financial contribution that conditions the consideration of the credit application,

- documenting integrally the level of the so-called 'disposable income' (Siemińska 2011).

2. Regarding corporate clients:

- market attractiveness of the credited project,

- the stage of advancement of the realised investment,

- the developer's own financial contribution,

- the amount of the realised surface presold,

- the credit history, etc.

Moreover, automatic systems of data processing used in loan granting procedures, such as, for example: scoring methods (Hutchison et al. 2007), the so-called 'loan calculators', or credit ratings, and the bankruptcy prediction models (Rugenyte et al. 2010) have been increasingly popular among banks. It must be emphasized that more and more bankers perceive the validity of the problem of a reliable property evaluation, and, therefore, more and more frequently they either (apart from the above-mentioned inspections) order evaluations profes- sionally prepared by qualified real estate experts, or verify by themselves the correctness of assumptions and methods used in valuation surveys delivered by customers, or make on their own evaluations that are suited to the analyzed applications.

Also, due the improvement in the global economic situation in 2010, banks relaxed their credit policies applied to mortgage loans. At present, banks show less restrictive attitudes towards the assessment of potential customers' creditworthiness, and some banks have even stopped to require form clients the so-called 'own financial contribution' while purchasing residential real estate, or have prolonged the payment period which allows granting larger loans.

The overall debt resulting from housing loans granted in Poland in the years 2002-2011 is presented in Figure 3.

The second parameter that affects the demand for residential real estate, i.e., the size of the interest charged on mortgage loans, is dependent primarily on the macroeconomic situation and the level of interest determined in Poland by the Monetary Policy Council which, in the first half of 2011, raised the interest rate as many as four times. That usually leads to an increase in interest rates charged on loans offered in the domestic currency (in Polish zlotys) ${ }^{1}$ and, consequently, to an increase in the value of loan instalments. The situation becomes even more complex if we consider foreign currency loans (particularly loans in Swiss francs) that were so popular in Poland until recently.

The substantial strengthening of that currency noted in the mid-2011 resulting from the present global market situation causes that the dynamics of the growth in credit instalments is especially painful for borrowers. Such a situation also affects some banks which taking into account the risk level have decided to withdraw from their offers loans in Swiss francs. The quickly growing interest rates in 2011 are partially compensated by low commissions and charges that constitute a fixed element of the loan interest rate. As pointed out by bankers, we should not expect any further reduction in fixed credit costs.

Shaping the demand on the residential real estate market is to a large degree dependent on the state's policy determining the financial support in the purchase of residential real estate. For many years Poland was offering various support programmes, however, at present the focus is on the so-called 'Rodzina na Swoim' (Family's Own Home) programme aimed at providing the state support in the payment of interest charged on housing loans. The programme has already covered a lot of families and it is estimated that every fourth mortgage loan is granted within the preferential 'Rodzina na Swoim' programme (Raport AMRON 2011). However, because of the present priorities set within the public finance policy a decision was made to cease that form of subsidizing housing loans by the end of 2012 .

1 The interest rose in the first half of 2011 by as much as $0.74 \%$ and reached the level of 4.7\%. On 8-9 November 2011 the Monetary Policy Council decided to keep the NBP interest rates unchanged - reference rate at $4.50 \%$ on an annual basis. 


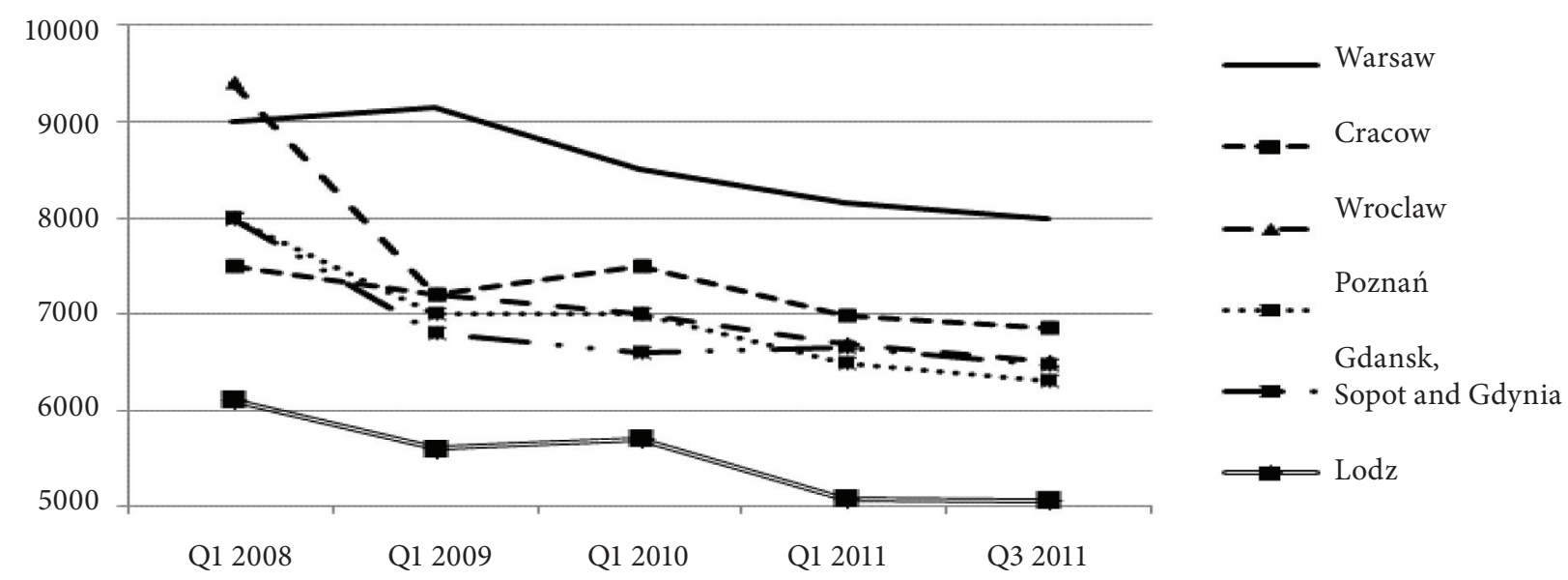

Fig. 2. Average prices on the property developers market in major Polish cities, in PLN/sq.m (Source: Rynek mieszkaniowy $w$ Polsce III Q 2011. Reas, Warsaw 2011)

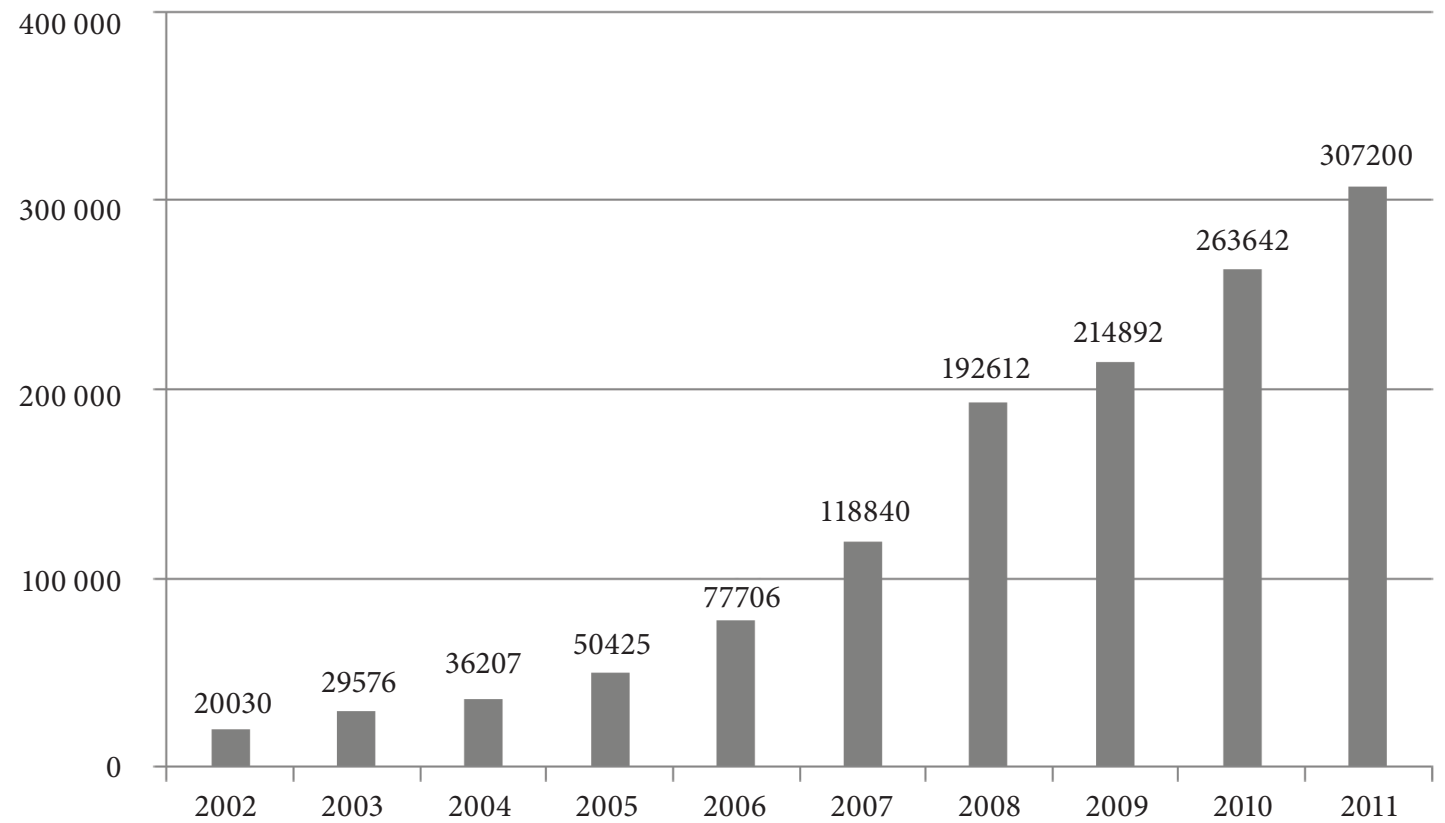

Fig. 3. The overall debt resulting from housing loans granted in the years 2002-2011 (in mln PLN)

Source: Ogólnopolski raport o kredytach mieszkaniowych i cenach transakcyjnych nieruchomości, AMRON-SARFiN, Związek Banków Polskich, September 2011

\section{Conclusions}

To summarise, the improvement on the market in Poland noted in the years 2010 and 2011 discussed at the beginning of this paper concerns all the following key elements of the market:

1. increased availability to mortgage loans due to a significant relaxation of banks' credit policies,
2. increased interest (due to the already announced finishing of the programme) in the governmental financial support given within the 'Rodzina na swoim' programme,

3. property developers' increased activity in undertaking new projects as well as in restarting the previously suspended investments, 
4. better adjustment of designs to financial possibilities of buyers,

5. a fall in prices of residential real estate which is beneficial for potential buyers.

It must be emphasised at the end that, similar to other sectors of the economy, the real estate market and the banking sector need to be continuously monitored and modified. At present, more and more debates are held on the necessity of institutional, legal, and, maybe most importantly, of mental changes. The practice proves undoubtedly that various problems of the banking sector being involved in financing the real estate market are related to the phenomenon of information asymmetry and moral hazard which without a strict control and suitable legal regulations is likely to thwart even the best institutional and legal solutions. At present more and more attention is being paid to CSR - Corporate Social Responsibility - whose eligibility and the need to apply it is revealed particularly in marginal economic conditions (Bogle 2009; Navickas, Kontautienè 2011).

\section{References}

Bogle, J. C. 2009. Enough: True Measures of Money Business and Life. New Jersey: J. Wiley \& Sons.

Dehesh, A.; Pugh, C. 1996. The Cutting Edge 1996. Real Estate Cycles, Internationalised Transmission Mechanism and the Japanese 'Bubble' Economy, RICS Research [online], [cited 02 January 2012]. Available from Internet:

http://www.rics.org/site/download_feed.aspx?fileID=2228 \&fileExtension $=$ PDF

Hutchison, H.; Adair, A.; Leheny, I. 2007. Property Risk Scoring: the reporting of investment risk to clients, RICS Research Paper Series 7(1): 11-21.

Knight, F. H. 1921. Risk, Uncertainty and Profit. University of Boston Press, Boston, 11-16.

Krajewska, M. 2011. Planning conditions and the market value of real estate, in Siemińska, E. (Ed.). Investment on the Real Estate Market. Wydawnictwo Naukowe Uniwersytetu Mikołaja Kopernika, Toruń, 63-99. ISBN 978-83-231-2616-4.

Lorenz, D.; Trück, S.; Lützkendorf, T. 2006. Addressing risk and uncertainty in property valuation: a viewpoint from Germany, Journal of Property Investment and Finance 24(5): 400-433. http://dx.doi.org/10.1108/14635780610691904

Navickas, V.; Kontautiene, R. 2011. Influence of corporate philanthropy on economic performance, Verslas: teorija ir praktika [Business: Theory and Practice] 12(1): 15-23. http://dx.doi.org/10.3846/btp.2011.02

Ogólnopolski raport o kredytach mieszkaniowych i cenach transakcyjnych nieruchomości. 2011. AMRON-SARFiN, Związek Banków Polskich, September.
Palm, A. 2011. Konzepte zur kulturellen integration nach M\&A, Verslas: teorija ir praktika [Business: Theory and Practice] 12(1): 33-44. http://dx.doi.org/10.3846/btp.2011.04

Pyhrr, S. A.; Born, W. L. 1994. Real estate valuation, the effect of market and property cycles, Journal of Real Estate Rese$\operatorname{arch} 4: 456$.

Raport AMRON. 2011. System Analiz i Monitorowania Rynku Obrotu Nieruchomościami, SARFiN Związek Banków Polskich.

Raport o stabilności systemu finansowego [online], [cited 08 November 2011]. Available from Internet:

http://www.nbp.pl/home.aspx?f=/systemfinansowy/stabilnosc.html

Real GDP growth rate - volume [online], [cited 07 November 2011]. Available from Internet: http://epp.eurostat.ec.europa. $\mathrm{eu} / \mathrm{tgm} /$ table.do? tab=table\&plugin=1\&language=en\&pcod $\mathrm{e}=\mathrm{tsieb} 020$

Renaud, B. 1995. The 1985-94 Global Real Estate Cycle its Causes and Consequences. The World Bank Financial Sector Development Department. Policy research working paper.

Restart Ernst \& Young's 2011 - European attractiveness survey [online], [cited 10 November 2011]. Available from Internet: http://www.ey.com/GL/en/Issues/Businessenvironment/2011-European-attractiveness-survey

Rugenytė, D.; Menciūnienė, V.; Dagilienė, L. 2010. The importance of bankruptcy prediction and methods, Verslas: teorija ir praktika [Business: Theory and Practice] 11(2): 143-150. http://dx.doi.org/10.3846/btp.2010.16

Rynek mieszkaniowy w Polsce III Q. 2011. Reas, Warsaw.

Siemińska, E. 2010. Funkcjonowanie deweloperów mieszkaniowych w Polsce w (po)kryzysowych warunkach gospodarczych, Studia i Materiały Towarzystwa Naukowego Nieruchomości, Journal of the Polish Real Estate Scientific Society 18(3): 29-37.

Siemińska, E. 2011. Locating Capital in the Real Estate Market, in Siemińska, E. (Ed.). Investment on the Real Estate Market. Wydawnictwo Naukowe Uniwersytetu Mikołaja Kopernika, Toruń, 9-41. ISBN 978-83-231-2616-4.

Stiglitz, J. E. 2010. Freefall: America, Free Markets and the Sinking of the World Economy. New York: WW. Norton \& Company.

The construction industry - performance results in 2011, GUS Warsaw 2011 [online], [cited 15 December 2011]. Available from Internet: http://www.stat.gov.pl

The World Investment Report. Non-Equity Modes of International Production and Development, United Nations Conference on Trade and Development, UNCTAD/WIR/2011; sales no.: E.11.II.D.2. ISBN 978-92-1-112828-4, date of publication: 26.07.2011.

Ewa SIEMIŃSKA. Prof. UMK, Dr Habil of Nicolaus Copernicus University in Toruń, Poland, the Faculty of Economics and Management, the Department of Investment and Real Estate. Research interests: real estate market, financing, banking, investment. 